\title{
THE FOSSIL PROBOSCIDEA (MAMMALIA) FROM BAHIA STATE, BRAZIL: TAXONOMY, DESCRIPTION, AND NEW LOCATIONS
}

\author{
MARIANE ROSA (1), CAROLINA SALDANHA SCHERER (1) \\ Centro de Ciências Agrárias, Ambientais e Biológicas, Universidade Federal do Recôncavo da Bahia, \\ Rua Rui Barbosa, 710, Centro, Campus Universitário, 44380-000, Cruz das Almas, BA, Brazil. \\ rosa.m.ariane@hotmail.com,carolina_scherer@yahoo.com.br \\ LEONARDO DOS SANTOS AVILLA (1) \\ Laboratório de Mastozoologia, Departamento de Zoologia, Instituto de Biociências, Universidade Federal \\ do Estado do Rio de Janeiro, Av. Pasteur, 458, 501, Urca, 22290-240, Rio de Janeiro, RJ, Brazil. \\ leonardo.avilla@gmail.com
}

\begin{abstract}
Fossils of Proboscidea are abundant in Northeastern Brazil. This study presents the identification and description of Proboscidea fossils from eight natural tank deposits in the Bahia state. The specimens were identified based on comparison with available references and by direct analysis of collection specimens. The fossils from the municipalities of Caldeirão Grande, Nordestina, Teofilândia, and Guanambi were identified only at the order level, while the specimens from the municipalities of Santaluz and João Dourado were identified as Notiomastodon platensis. Moreover, five age classes were identified: immature, subadult, adult, mature adult, and senile-adult. The majority of the studied individuals are mature adults. The existing records of Proboscidea from Bahia included a total of 32 localities, and the present study increase in $22 \%$ these records.
\end{abstract}

Keywords: Notiomastodon platensis, Pleistocene, Quaternary, Megafauna, South America, Northeast Brazil.

RESUMO - Fósseis de Proboscidea são abundantes no nordeste do Brasil. Este estudo apresenta a identificação e descrição de fósseis de Proboscidea provenientes de oito depósitos naturais do tipo tanque do Estado da Bahia. Os espécimes foram identificados com base em comparações com referências disponíveis e com análise direta a espécimes em coleção. Os fósseis dos municípios de Caldeirão Grande, Nordestina, Teofilândia e Guanambi foram identificados apenas ao nível de ordem, enquanto os espécimes provenientes dos municípios de Santaluz e João Dourado foram identificados como Notiomastodon platensis. Além disso, cinco faixas etárias foram identificadas: Imaturo, subadulto, adulto, adulto maduro e adulto senil. A maioria dos indivíduos são adultos maduros. Os registros existentes de Proboscidea na Bahia incluem um total de 32 localidades, e o presente estudo aumenta em $22 \%$ esse registro.

Palavras-chave: Notiomastodon platensis, Pleistoceno, Quaternário, Megafauna, América do Sul, Nordeste do Brasil.

\section{INTRODUCTION}

The first proboscideans originated in Africa, from where they diversified and dispersed across Eurasia and the Americas, reaching South America as part of the Great American Biotic Interchange (GABI) (Ubilla, 2009). The South American fossil proboscideans are represented by the genera Notiomastodon and Cuvieronius (Mothé et al., 2012, 2017).

The first evidence of Proboscidea from Brazil was collected by Peter W. Lund in the karst region of Lagoa Santa, Minas Gerais state (Mothé et al., 2017). In the Northeastern region of Brazil, the fossil records of Proboscidea are abundant, with evidence in all the states (Simpson \& PaulaCouto, 1957; Mothé et al., 2017).

One of the first records from Bahia was documented by Holland in 1920, who studied the specimens collected from
Pedra Vermelha in 1912 (Cartelle, 1992). The Proboscidea records in the State of Bahia also include the municipalities of Vitória da Conquista, Paulo Afonso, Pilão Arcado, Jeremoabo, Campo Formoso, Santaluz, Ourolândia, Jacobina, Serrinha, Rio de Contas, Palmas do Monte Alto, Gentio d'Ouro, Coronel João Sá, Matina, Baixa Grande, Quijingue, Jaguarari, Anagé, and Guanambi (Paula-Couto, 1953; Simpson \& Paula-Couto, 1957; Cartelle, 1992; Dantas \& Tasso, 2007; Dantas \& Zucon, 2007; Riff et al., 2008; Ribeiro \& Carvalho, 2009; Machado et al., 2011; Dantas et al., 2013; Farias et al., 2013; Lôbo et al., 2013; Silva et al., 2014; Scherer et al., 2017; Silva et al., 2019).

New fossil records of Proboscidea are found until the present day, especially in tank deposits, which are frequent in the Bahia state (e.g. Scherer et al., 2017). Mothé et al. (2017) argued that despite the abundance of Proboscidea 
fossils in Brazil, especially in the Northeastern region, the lack of diagnostic specimens is a major limitation, since it is not possible to identify species of Proboscidea in over $60 \%$ of the Brazilian sites. Thus, in an attempt to increase the information on this group, this study revised, identified, and described the Proboscidea fossils from tank deposits found in six municipalities of Bahia State.

\section{LOCATIONS AND THEIR GEOLOGY}

The fossils studied were recovered from eight natural tanks, located in six municipalities of the Bahia state (Figure 1). Tanks are natural depressions formed by physico-chemical weathering in fractures on basement rock outcrops that seasonally accumulate rainwater (Araújo-Júnior et al., 2013).

In the following we present information on the seven tank deposits where the material studied here was collected:

I. Tanks from Santaluz municipality, located about $300 \mathrm{~km}$ from Salvador, the capital of Bahia state, and, in the localities of Lagoa Escura (11 $11^{\prime} 42^{\prime}$ 'S, $39^{\circ} 14$ '40”'W; Figure 2A), Várzea Funda (11 ${ }^{\circ} 11^{\prime} 13.02^{\prime}$ 'S, $39^{\circ} 25^{\prime} 41.19^{\prime \prime} \mathrm{W}$; Figure 2B), and Vargem Grande $\left(11^{\circ} 16^{\prime} 55.96^{\prime \prime} \mathrm{S}, 39^{\circ} 34^{\prime} 30.12^{\prime \prime} \mathrm{W}\right.$; Figure 2C). These fossils were found during excavations to use the tanks as water deposits during dry season. The Lagoa Escura deposit is an approximately three-meter-deep pond, where the upper layers are composed of clay and the fossils are located in a conglomerate of gray clay matrix above a layer of coarse sand (Scherer et al., 2013). However, these fossils were not collected in situ, because they had already been removed by the local population. Similarly, the fossils in the tank at Vargem Grande were collected after excavation by the local population. As this tank was filled with water, it was not possible to verify the sedimentary content. The Várzea Funda tank was the only site from where the fossils were collected in situ, in the middle of light gray colored clay-sandy sediments.

II. In the municipality of João Dourado (Figure 2F), located in the central western region of Bahia state $\left(11^{\circ} 16^{\prime} 28^{\prime \prime} \mathrm{S}\right.$, $\left.41^{\circ} 35^{\prime} 46^{\prime \prime} \mathrm{W}\right)$. In this case, the fossils were collected from excavations conducted in the extraction of clay to be used in the regional pottery industry. The fossiliferous level was about $1 \mathrm{~m}$ below the soil surface, representing the bottom of the tank having a base of limestone. It is surrounded by limestone, which could be the external borders of the tank (Lobo et al., 2013).

III. From the Caldeirão Grande municipality (Figure 2E), in the central northern- region of the Bahia state $\left(10^{\circ} 58^{\prime} 16^{\prime \prime} \mathrm{S}\right.$, $\left.40^{\circ} 16^{\prime} 52^{\prime \prime} \mathrm{W}\right)$. The fossils were found during excavations made by the local population to use the tank as a water reservoir (Santos \& Scherer, 2013). The fossils were found in conglomerates of dark gray colored clay matrix.

IV. From Lagoa das Abelhas (149'32', S, 4246’22”W) (Figure 2D), Guanambi municipality, central southern Bahia State. The fossils from this site were recovered from sediments which were previously excavated from the inside of the tank during the construction of the Ferrovia de Integração Oeste-Leste (FIOL), a state railroad. This tank is located in the Guanambi Batholith (Geobank/ CPRM, 2015). The fossils in this tank were found within clay, light gray-colored sediments which glow dark with pebbles of several sizes.

V. From a tank in the Lagoa dos Caboclos locality $\left(11^{\circ} 24^{\prime} 34.9^{\prime \prime} \mathrm{S} 38^{\circ} 52^{\prime} 48.8^{\prime \prime} \mathrm{W}\right.$ ) (Figure 2G), in the municipality of Teofilândia, northeast of Bahia state. This municipality is about $194 \mathrm{~km}$ distant from Salvador. The fossils were collected from tailings removed from the tank, which caused most of the fragmentation. As the tank was being used as a water reserve, it was not possible to obtain information about the sediments that filled the tank.

There is no information on fossil deposits from Lagoa da Gameleira, Nordestina municipality, because the survey data are lost.

\section{MATERIAL AND METHODS}

The studied specimens are part of the Paleontological Collection of the Museu de Zoologia e Paleontologia from the Universidade Federal do Recôncavo da Bahia (UFRB). The identifications of the fossil were performed by comparisons with specimens deposited at the Museu Nacional and Museu de Ciências da Terra both located in Rio de Janeiro city, southeastern Brazil.

This study followed the taxonomy propositions of Mothé et al. (2012) and Mothé et al. (2017). The fossils were identified from figures and descriptions presented by Smuts \& Bezuidenhout (1994), Marcon (2008), Ferretti (2010), Mothé et al. (2010; 2012), and Molena (2012). The measurements were made according to Ferretti (2010) and Molena (2012), while the dental nomenclature was based on Tassy (1996) modified by Marcon (2008) (Figure 3). The classification of dental wear was based on Simpson \& Paula-Couto (1957) and Mothé et al. (2010) (Table 1).

Abbreviations. DGM, Museu de Ciências da Terra, Rio de Janeiro; MGUFBA, Museu de Geociências of Universidade Federal da Bahia; MN, Museu Nacional, Universidade Federal do Rio de Janeiro; UFRB-PV, Paleontological Collection of the Museu de Zoologia e Paleontologia from the Universidade Federal do Recôncavo da Bahia; $\mathbf{M}^{2}$, upper second molar; $\mathbf{M}^{3}$, upper third molar; $\mathbf{M}_{1}$, lower first molar; $\mathbf{M}_{2}$, lower second molar; $\mathbf{M}_{3}$, lower third molar.

\section{SYSTEMATIC PALEONTOLOGY}

Order PROBOSCIDEA Illiger, 1811

(Figures 4-5)

Material. MGUFBA1492: left dentary with $\mathrm{M}_{3}$ tooth, MGUFBA1491: right dentary with $\mathrm{M}_{3}$ tooth, collected from Nordestina municipality. MGUFBA1494: fragment of incisor tooth collected from Teofilândia municipality. UFRB-PV759: fragment of the right $\mathrm{M}^{3}$ tooth, taken from Lagoa das Abelhas, 


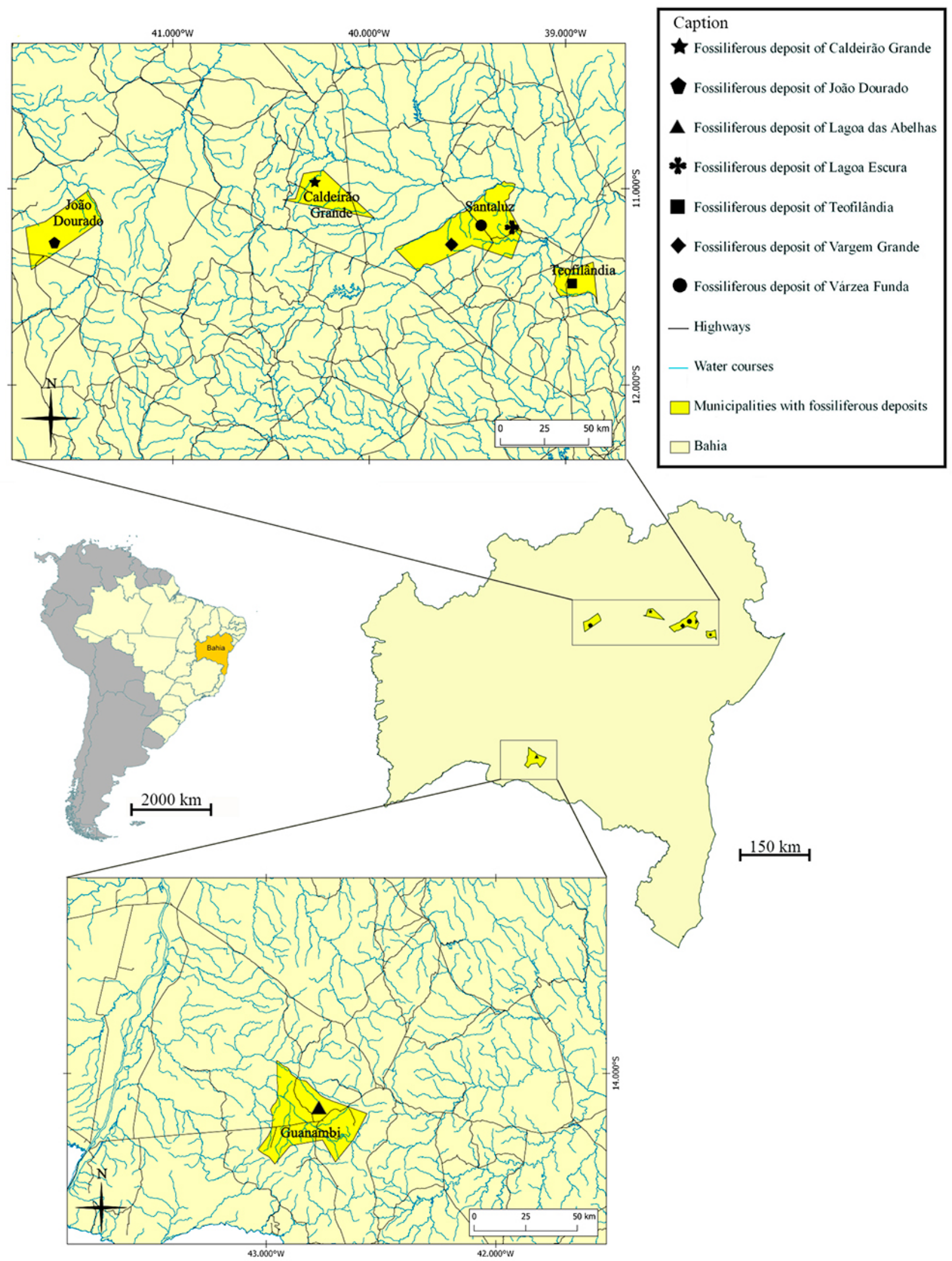

Figure 1. Location of the Bahia State, highlighting the municipalities and fossiliferous deposits, from where the studied material was collected. 

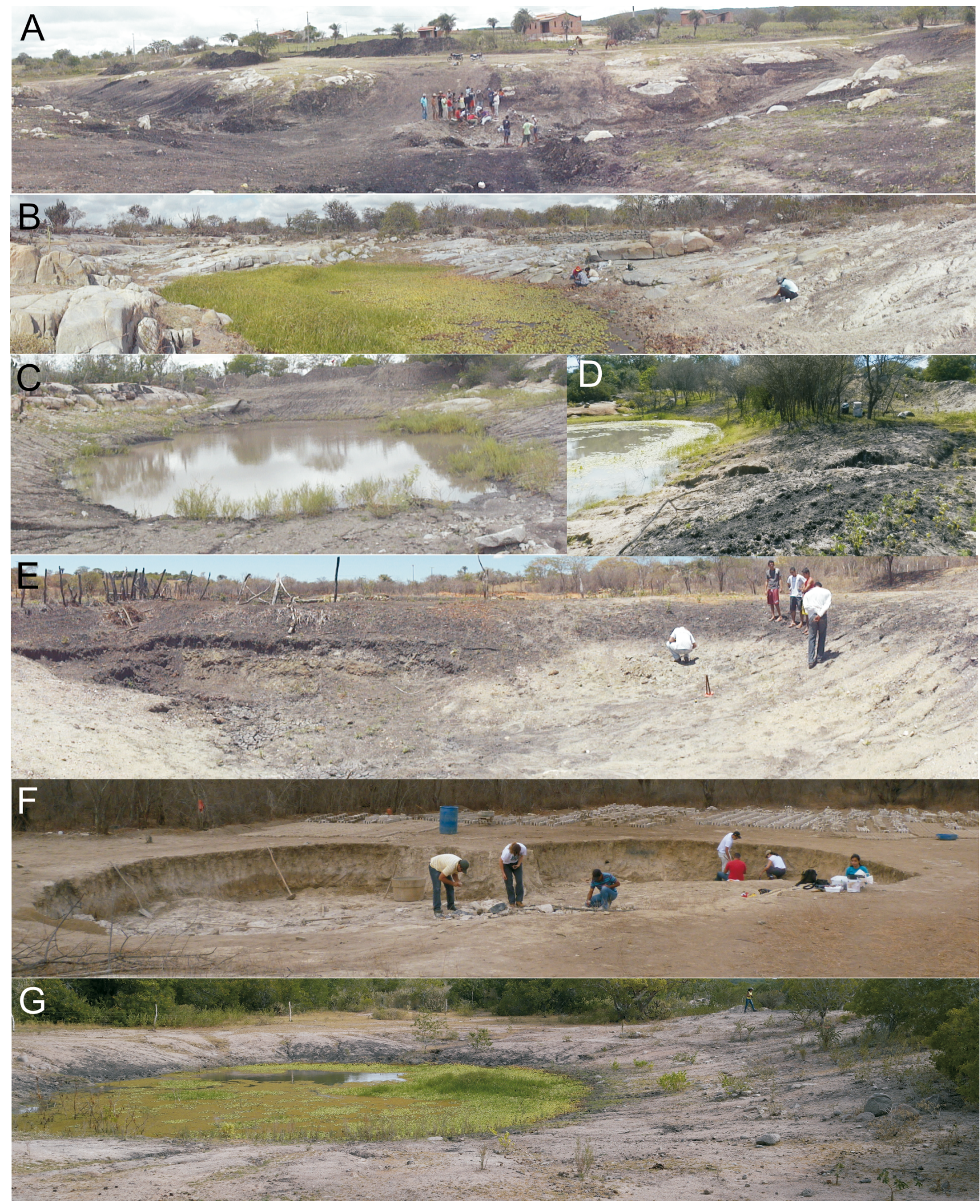

Figure 2. General view of natural tanks in the localities of Lagoa Escura (A), Várzea Funda (B), Vargem Grande (C) at Santaluz municipality, Lagoa das Abelhas (D) at Guanambi municipality; Caldeirão Grande (E), JoãoDourado (F) and Teofilândia (G) municipalities. 

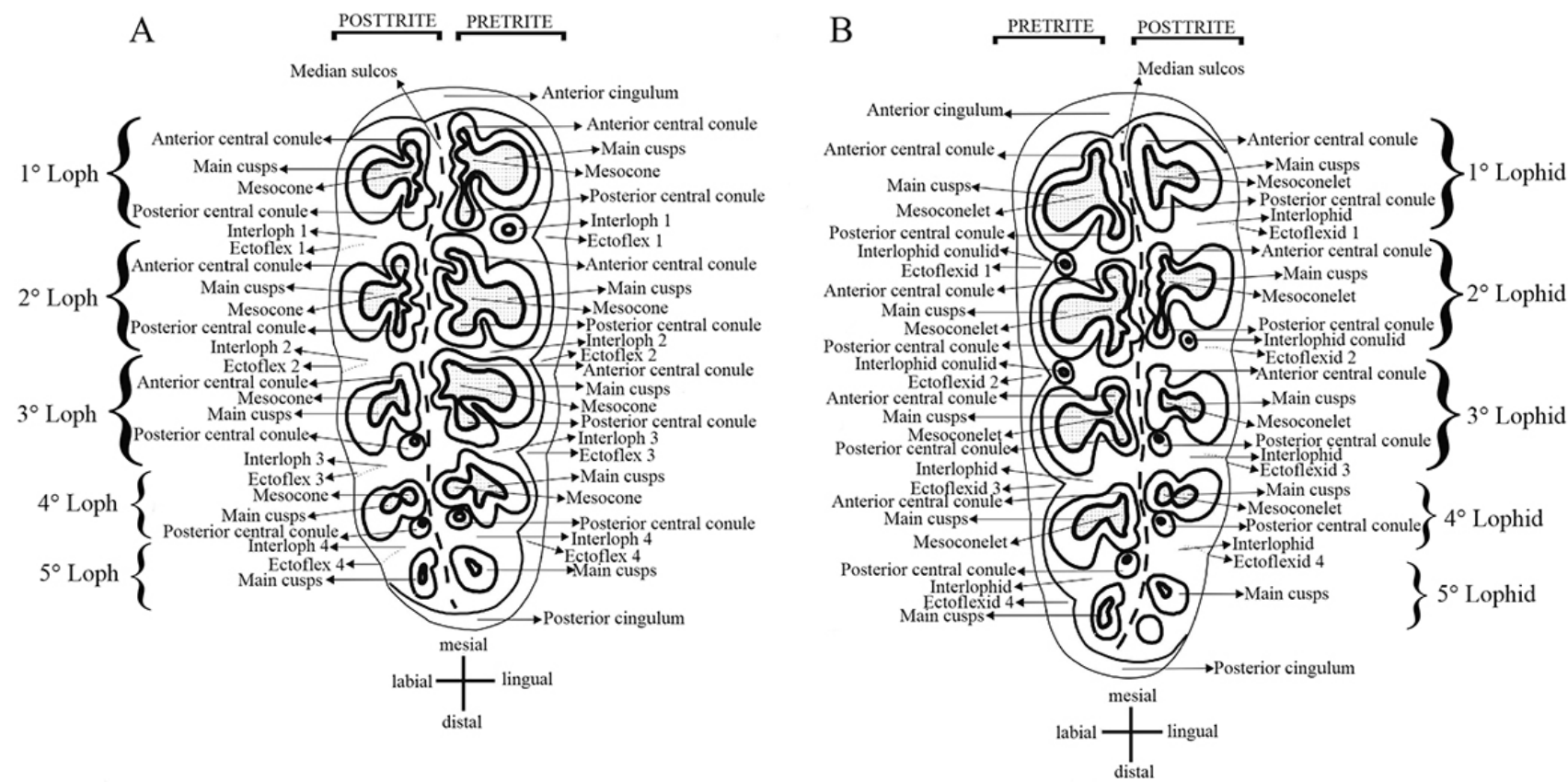

Figure 3. Dental terminology used to describe upper and lower molars. A, M³ right; B, M left. From Tassy (1996), adapted by Marcon (2008).

Table 1. Molariform teeth wear stages established by Simpson \& PaulaCouto, 1957. Intermediate stages correspond to numbers 1,2 , and 3. *Taken from Mothé et al. (2010).

\begin{tabular}{cl}
\hline Wear stages & \multicolumn{1}{c}{ Wear description } \\
\hline 0 & Tooth formed but not erupted \\
$0+$ & Tooth erupted but not worn \\
1 & Wear present only in anterior lophids \\
2 & Light wear in all lophids \\
3 & Great wear with lophids still visible \\
4 & Severe wear with lophids partially or totally obliterated \\
\hline
\end{tabular}

Guanambi municipality. UFRB-PV523: incomplete right ulna, collected from Caldeirão Grande municipality.

Description. Mandible: MGUFBA1491 is a right complete dentary with minor wear in the symphysis region (Figure $4 \mathrm{~A}$ and $\mathrm{A}^{\prime}$ ). In the third lophid of the $\mathrm{M}_{3}$, it was possible to observe only the first cones having nearly the complete format of a clover. In the fourth lophid, the two main cusps were visible, the one from the region of the pretrite is larger than the posttrite one. Due to wear, it was not possible to distinguish the posterior central cones from the main cusp of the posttrite. In the fifth lophid, the two cusps were nearly joined as one due to the wear, forming oval figures. As per Mothé et al. (2010), the specimen MGUFBA1491 showed stage 4 wear. MGUFBA1492 also had a left dentary (Figure $4 \mathrm{~B}$ e B') showing fragmentation at the base of the anterior region where the tooth is inserted, and in the posterior region. Although the $M_{2}$ alveolus was visible, only the $M_{3}$ was present. The $\mathrm{M}_{3}$ from this specimen is almost complete; only the pretrite region and half of the first lophid of posttrite is fragmented and with extensive wear. In the second lophid, the main cusps are visible in clover-like forms, but the conules between the lophids are not visible. In the third lophid, the main cuspids in the form of clover is also present, and the posterior conules were fused to them. In the fourth lophid, the main cusp of the pretrite was greater than the main cusp of the posttrite, and the central posterior conules were also visible. In the fifth lophid, the main cusps are present in a conical format, and two small accessory cusps were also visible. As per Mothé et al. (2010), the specimen MGUFBA1492 showed wear stage 1. Dentition: the specimen MGUFBA1494 showed a highly fragmented incisor. Due to fragmentation, it was not possible to ascertain the exact position of the specimen in vivo. Although the concentrically dentin layers could be observed in the specimen, the enamel layer was not preserved. Following Mothé et al. (2010), this specimen was identified in the wear stage 0+. The specimen UFRB-PV759 (Figure $5 \mathrm{~A}$ ) has an incomplete upper third molar, and only half of the fourth and the fifth lophs are observable. In the fourth loph, the middle portion of the main cusp was fragmented, and the posterior central cones were present. In the fifth loph, the two main cusps have two fusioned mesoconulets. Ulna: the specimen UFRB-PV523 (Figure 5B) is a right incomplete ulna, belonging to a juvenile individual nearing adulthood. 

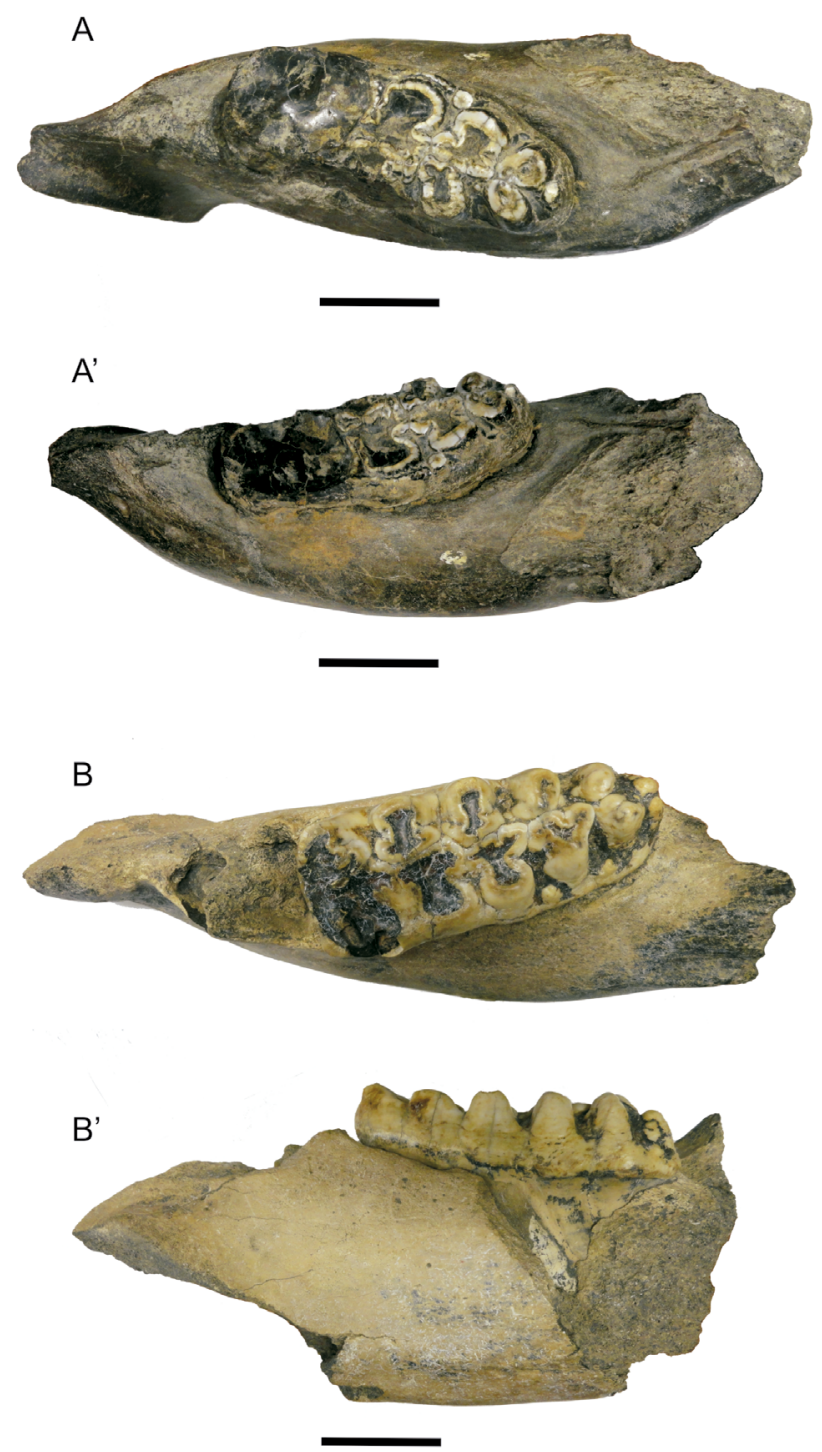

Figure 4. Dentaries of Proboscidea. A, right dentary (MGUFBA1491) in occlusal view (A) and lateral view (A'); B, left dentary (MGUFBA1492) in occlusal view (B) and lateral view (B'). Scale bars $=8 \mathrm{~cm}$.

It was observed that the region of the olecranon was already fused to the diaphysis, but the olecranon tubercle region was not fused yet. The specimen also showed a fragmented distal region and only the coronoid process was preserved. This was a somewhat narrow, concave facet, the lateral side of which had a slightly rough area while the medial face contained a fine facet - the radial notch.

Comments. The studied specimens were compared with some ones previously attributed to Stegomastodon platensis (e.g. Marcon, 2008), as shown below. As mentioned above, this species was synonymized with Notiomastodon platensis by Mothé et al. (2012). The $\mathrm{M}_{3}$ of MGUFBA1491 and the specimen MN2601-V described by Marcon (2008) showed similarity in the position of the cusps. Although the cusps in MN2601-V had less weared than MGUFBA1491, it was clear that both the specimens had the same number of cusps in the fourth and fifth lophs. Comparison of the specimen
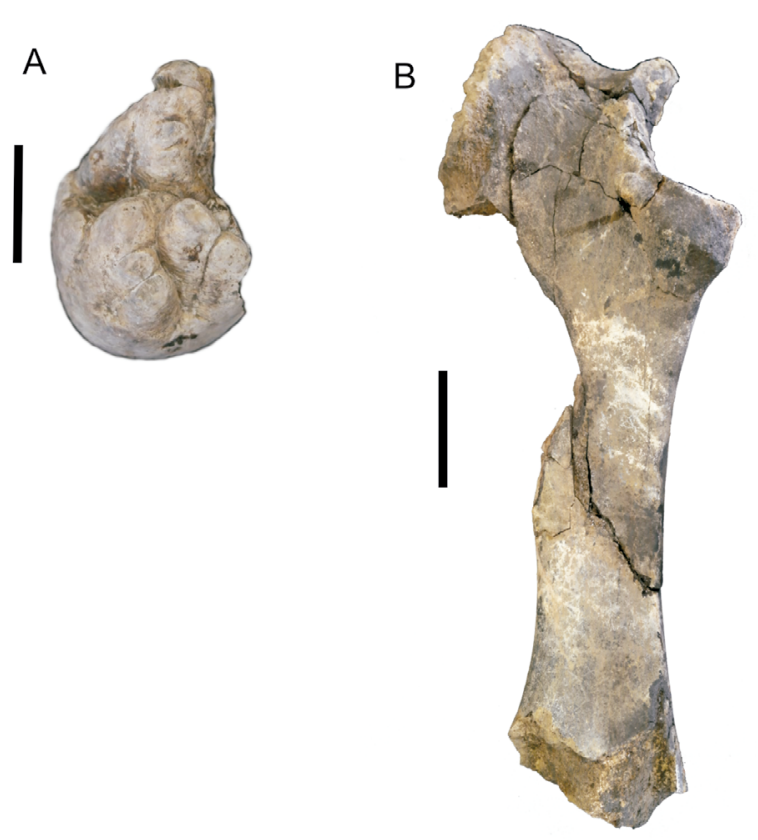

Figure 5. Specimens of Proboscidea. A, fragment of right $\mathrm{M}^{3}$ (UFRB-PV759) in occlusal view; $\mathbf{B}$, incomplete right ulna (UFRB-PV523) in lateral view. Scale bars: $\mathrm{A}=5 \mathrm{~cm} ; \mathrm{B}=8 \mathrm{~cm}$.

MOM 0005 described by Marcon (2008) with the specimen MGUFBA1492 showed a clear similarity between the two. Although the trefoil-shaped figures were quite similar in both specimens, MOM 0005 did not show accessory cusps in the last loph. However, this is a characteristic that may vary across different specimens. According to Mothé et al. (2012), spiraling of the enamel band on the upper incisors is present in individuals of Cuvieronius hyodon, while it is absent in Notiomastodon platensis. The specimen MGUFBA1494 is highly fragmented, and it was not possible to observe this characteristic. Thus, it was identified only as a specimen of the Order Proboscidea. The morphology of the specimen MCP 3407-PV described by Marcon (2008) was similar to UFRB-PV759; the shape and position of their main cusps in the fifth loph were similar and the specimen MCP 3407PV also showed a few small cones. All the measurements of the specimen UFRB-PV523 were within the range for the order Proboscidea (Table 2). The studied specimen had a slight curvature in the olecranon region, which was also observed in the specimens DGM80-M and DGM46-M used for comparison. The coronoid process of the studied specimen was concave and shallow, similar to the other specimens observed. According to Mothé et al. (2012), one of the major differences between the two South American species is the greater complexity in the number of auxiliary cusps in the molars of $N$. platensis, in comparison to $C$. hyodon. Due to the incomplete cusps of the specimens studied and similarity of the post-skull elements between the two species, it was not possible to identify them to the species level, and they were attributed to the only order recorded in South America. 
Table 2. Comparative measurements (in mm) of ulnas UFRB-PV523 and UFRB-PV2126 with the specimens DGM46M, 80M and 148M, as well as those observed in the literature. Abbreviations: DAP, depth through anconeus process; PEW, proximal extremity width; SDW, smaller diaphysis width; SDP, smaller diaphysis profundity; LCPW, lateral coronoid process width; MCPW, medial coronoid process width. *Dimensions taken from Molena (2012).

\begin{tabular}{|c|c|c|c|c|c|c|}
\hline Specimen & DAP & PEW & SDW & SDP & LCPW & MCPW \\
\hline UFRB-PV 523 & 181.4 & - & 102.3 & 100.8 & 71.3 & - \\
\hline UFRB-PV 2116 & - & 221.9 & - & - & 73 & 83.8 \\
\hline DGM 46-M & 205.2 & 189.2 & 97.2 & 96.8 & 57.6 & 78 \\
\hline DGM 80-M & 201.2 & 184.4 & 103.4 & 87.4 & 70.9 & 80.3 \\
\hline DGM 148-M & - & - & 85.4 & 73 & 62.7 & 77.7 \\
\hline MCL 18.557/09 & $179.8^{*}$ & $229.5^{*}$ & $113.5^{*}$ & $107.3^{*}$ & - & - \\
\hline MACN PV-10 III & $122.7^{*}$ & $184 *$ & $82.2 *$ & $81.1^{*}$ & - & - \\
\hline
\end{tabular}

Notiomastodon Cabrera, 1929

Notiomastodon platensis (Ameghino, 1888)

(Figures 6-8)

Material. UFRB-PV4140, 4142, 4143, 4147, 4157, 4248, 4250, 4251, 4252, 4253: fragments of incisor without enamel, UFRB-PV4137, 4239: fragments of incisor with enamel, UFRB-PV4279: fragment of the mandible, UFRBPV4176: incomplete $M_{1}$ from the locality of Vargem Grande, municipality of Santaluz. UFRB-PV3627: fragments of incisor without enamel from the locality of Várzea Funda, municipality of Santaluz. UFRB-PV530, 663, 668, 674, 707, 730, 738, 739, 820, 821, 822, 951, 1032, 1034, 1038, 1039, $1085,1092,1101,1109,1116,1119,1120,1121,1123,1124$, $1125,1126,1128,1129,1130,1132,1133,1134,1135,1136$, 1949, 1969, 2014, 3888, 3889, 3890, 3891, 4281, 4289, 4290: fragments of incisor without enamel, UFRB-PV1084, 1089, $1110,1114,1118,1131,4280$ : fragments of incisor with enamel, UFRB-PV736: fragment of left $\mathrm{M}_{3}$, UFRB-PV669: fragment of cervical vertebra C7, UFRB-PV1096: fragment of cervical vertebra, UFRB-PV660, 4034: fragments of thoracic vertebra, UFRB-PV2116: fragment of right ulna, UFRB-PV534: right astragalus, UFRB-PV1689: left proximal phalanx of the finger IV from the locality of Lagoa Escura, municipality of Santaluz. MGUFBA1493: incomplete incisor tooth, UFRB-PV376: incomplete right $\mathrm{M}_{2}$, UFRB-PV377: incomplete right $\mathrm{M}_{3}$ from the municipality of João Dourado. Description. Mandible: the specimen UFRB-PV4279 is a fragment of the dentary. Although it was not possible to observe several structures due to fragmentation, part of a molar with visible cusps is formed, before eruption, on the ventral face. According to the classification of Mothé et al. (2010), this tooth was in stage 0 of wear. Dentition: the specimens UFRB-PV530, 663, 668, 674, 707, 730, 738, 739, $820,821,822,951,1032,1034,1038,1039,1084,1085$, 1089, 1092, 1101, 1109, 1110, 1114 (Figure 7A and A'), 1116, $1118,1119,1120,1121,1123,1124,1125,1126,1128,1129$, $1130,1131,1132,1133,1134,1135,1136,1949,1969,2014$, $3627,3888,3889,3890,3891,4137,4140,4142,4143,4147$, 4157, 4239, 4248, 4250, 4251, 4252, 4253, 4280, 4281, 4289, 4290 are incisor fragments whose position (right or left) was not possible to ascertain. Some of these fragments could be parts of a single tooth which had fragmented due to the improper collection. When the specimens UFRB-PV820, 822, 1110,1114 , and 4280 were observed in sectional view, the concentric layers of dentin were visible. Only the specimens UFRB-PV1084, 1089, 1110, 1114, 1118, 1131, 4137, 4239, and 4280 contained small areas where the enamel cover was preserved. It is not possible to observe spiraling of the enamel band in the teeth on study. The specimen MGUFBA1493 is an incomplete tusk with fragmented ends. However, the visible cone shape of this specimen identified it as the distal portion. In this specimen, it was still possible to observe the layers of dentin arranged concentrically. The specimen UFRB-PV376 (Figure 6A) is an incomplete second upper molar, and only the posttrites of first, second, and the beginning of the third lophs were preserved. In the first loph, the main cusp and the posterior central cones have a trefoil shape. In the second loph, the same pattern is observable in main cusps and accessory conelets. In the third loph, only the anterior central cones are visible. The specimen is attached to the maxillary bone, and due to the fragmentation, a portion of the molar root is visible. The specimen is at the wear stage 3 (Mothé et al., 2010). The specimen UFRB-PV4176 (Figure 6B) is an incomplete left $\mathrm{M}_{1}$, and only the final part of the third cusp is missing. The specimen is trilophodont and has little wear with complete cusps, and the trefoil shape is not evident. The specimen UFRB-PV4176 could be assigned to level 1 of wear according to Mothé et al. (2010). The specimen UFRB-PV736 (Figure 6C) is a fragmented $M_{3}$ in which only the fourth and fifth lophids are observable. The main cusps of the fourth lophid are present, but with fragmented extremities. Also, it is possible to observe the posterior central conulids in close proximity to the main cusps. In the fifth lophid, it was possible to observe the main cusps and the two adjacent conulids. When analyzing the wear stages described by Mothé et al. (2010), this specimen was observed to be in stage 2, presenting slight wear at all its cusps. The specimen UFRB-PV377 is a third right lower molar. Only half of the third lophid to the fifth lophid were preserved. In the third lophid, half of the two main cusps could be observed, wherein the second had a higher level of wear. In the fourth and fifth lophids, only a few cusps were visible. In the fourth lophid, the region of the pretrite was visible only on the main cusp without signs of wear, whereas the region of the posttrite and the central posterior conules were observed 

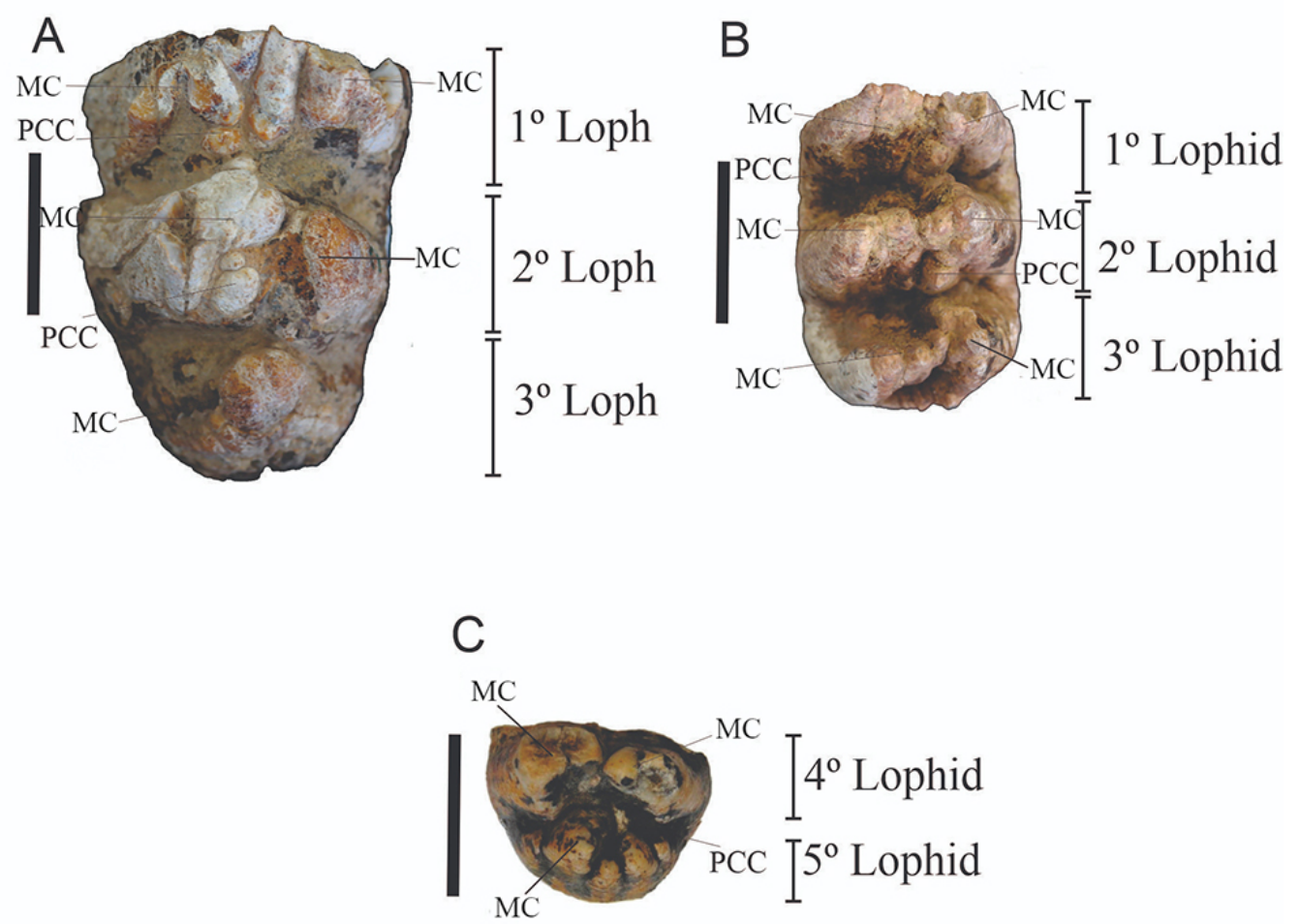

Figure 6. Notiomastodon platensis. A, $\mathrm{M}^{2}$ incomplete (UFRB-PV376) in occlusal view; B, $\mathrm{M}_{1}$ incomplete (UFRB-PV4176) in occlusal view; $\mathbf{C}$, fragment of $\mathrm{M}_{3}$ left (UFRB-PV736) in occlusal view. Abbreviations: MC, main cusps; PCC; posterior central conule. Scale bars $=5 \mathrm{~cm}$.
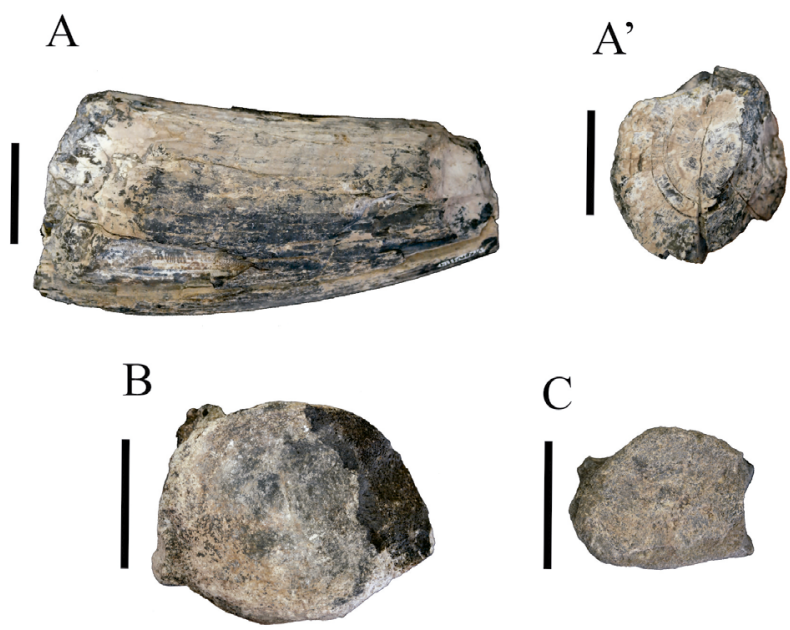

$\mathrm{D}$

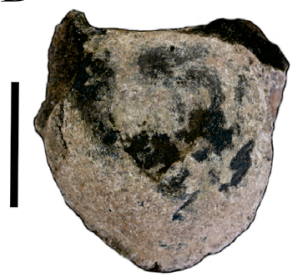

$\mathrm{E}$

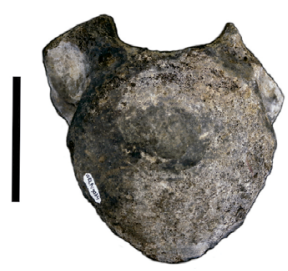

Figure 7. Notiomastodon platensis. A, incisive tooth fragment (UFRBPV1114) in lateral view (A) and sectional view (A'); $\mathbf{B}$, fragment of cervical vertebra C7 (UFRB-PV669) in caudal view; $\mathbf{C}$, fragment of cervical vertebra (UFRB-PV1096) in cranial view; D, fragment of thoracic vertebra (UFRBPV660) in cranial view; E, fragment of thoracic vertebra (UFRB-PV4034) in cranial view. Scale bars: $A=5 \mathrm{~cm} ; B-E=8 \mathrm{~cm}$. on the main cusp with little wear. In the fifth lophid, the two main cusps were united into one cusp, but a slight notch at the center demarcated each one. The specimen UFRB-PV377 is in the wear stage 2 (Mothé et al., 2010).

Vertebrae: the specimen UFRB-PV669 (C7) (Figure 7B) is a rounded and latero-laterally wide vertebral body of a cervical vertebra, which is short and compressed in the cranio-caudal axis. Although the vertebra is not fully preserved, it is possible to see the oval-shaped caudal fovea for the rib on the caudal face, similar to the specimen of Haplomastodon chimborazi (Proaño, 1922) described by Ferretti (2010). The portions of the vertebral arch were also visible in the cranial region, below which the grooves forming the vertebral notch were present. In the specimen UFRB-PV1096 (Figure 7C), only the rounded vertebral center was preserved. It is laterally wide and its size is much smaller than in other vertebrae. Their position was identified by comparison with Ferretti (2010). It was possible to observe the beginning of the vertebral arch on the right side and in posterior view, it was noticeable that the vertebral center did not have grooves and was nearly straight. The thoracic vertebrae were characterized by the presence of cranial and caudal costal joint facets and reduced transverse processes. The vertebral body of specimen UFRB-PV660 (Figure 7D) is extremely well preserved and has a more triangular shape. In an antero-posterior view, the specimen is short. The right and left caudal costal fovea were well preserved and oval-shaped, similar to the specimens of Notiomastodon platensis $(=H$. chimborazi) described by Ferretti (2010). It was also possible to locate the vertebral 
A
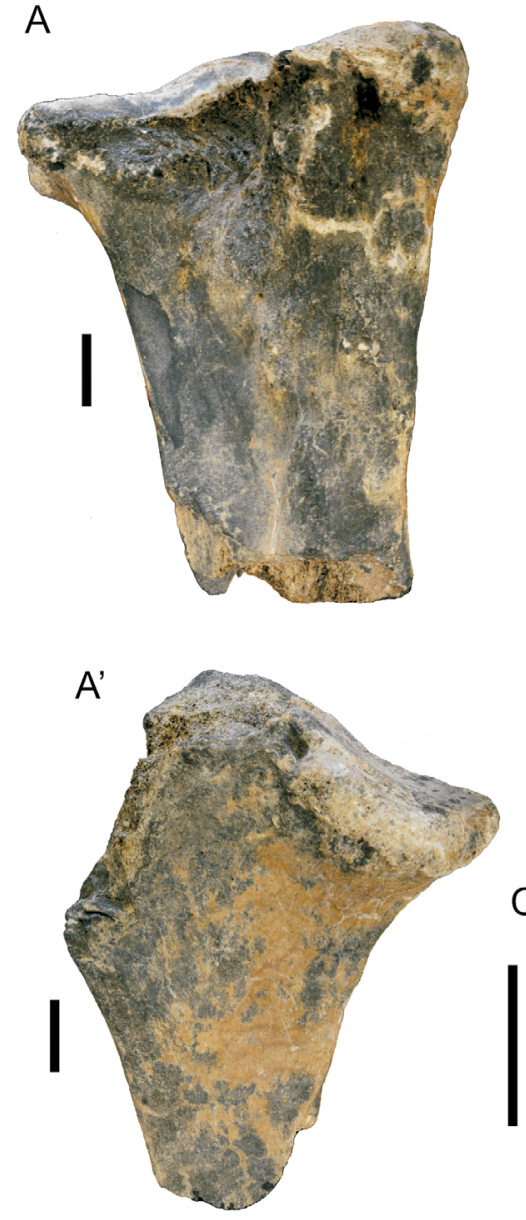
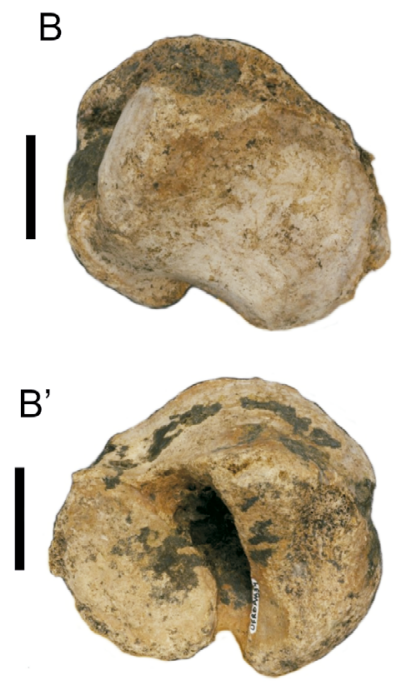

C

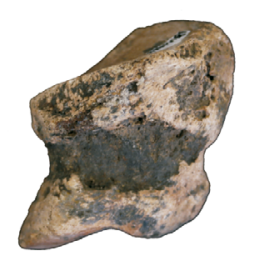

C'

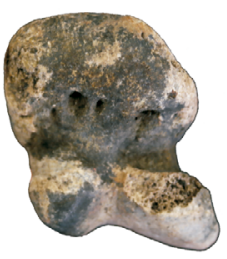

Figure 8. Notiomastodon platensis. A, fragment of right ulna (UFRB-PV2116) in cranial view (A) and lateral view (A'); B, right astragalus (UFRB-PV534) in proximal view (B) and distal view (B'); C, proximal phalanx of the finger IV left (UFRB-PV1689) in anterior $\left(\mathbf{C}^{\prime}\right)$ and posterior views $\left(\mathbf{C}^{\prime}\right)$. Scale bars $=5 \mathrm{~cm}$.

foramen and remnants of the vertebral arch in the upper region. The specimen UFRB-PV4034 (Figure 7E) also had a highly rounded triangular shape and its size was slightly smaller than UFRB-PV660. The vertebral arch was absent and only the right vertebral foramen was present in the upper region of the specimen. This position was rounded with a shallow groove, which allowed it to be identified according to Ferretti (2010).

Ulna: the specimen UFRB-PV2116 (Figure 8A and A') is a fragmented right ulna whose distal region was lost. The proximal region is broad with nearly triangular shape, and the olecranon was lost. The other two sides formed the lateral and medial coronoid process, which are similar to each other and has a shallow oval surface. A small pit called the radial facet could be observed between them, where the radial notch is present. It was observed that the entire borders of the specimen had a rough appearance; thus, possibly the specimen represents a senile individual. Pes elements: UFRB-PV534 (Figure 8B and B') is a right astragalus that has a flat, discshaped structure in a dorso-plantar side. The specimen is in a perfect state of preservation and it was possible to differentiate all facets of articulation. The dorsal part presented a broad and shallow trochlea for articulation with the tibia, which is a convex and had two elevations splited by a fairly smooth groove. Laterally, there are a small flat and oval-shaped facet to the fibula. In the plantar region, there two facets to the calcaneus separated by a wide and deep groove. The ectal facet is wider than long, while the opposite is valid for the sustentacular one. In the anterior face, there was a broad convex facet of the navicular. The specimen UFRB-PV1689 (Figure $8 \mathrm{C}$ and $\mathrm{C}^{\prime}$ ) is a proximal phalanx of the left IV digit. It is complete with few minor wears, with all facets of articulation.

Comments. Only the localities of Santaluz and João Dourado municipalities contained diagnostic specimens according to Mothé et al. (2012). Therefore, the materials associated with these specimens were assigned to $N$. platensis. Besides, the studied specimens were compared with some ones previously attributed to Notiomastodon platensis (=Stegomastodon platensis). There is no confirmation that these materials have been reassigned, but by the species distribution according to Mothé et al. (2012) all individuals previously identified as Stegomastodon platensis can be attributed to Notiomastodon platensis. Due to the presence of the erupted molar, the mandible fragment UFRB-PV4279 can be attributed to an adult individual (Laws, 1966). According to Mothé et al. (2012), one of the major diagnostic characteristics of Cuvieronius hyodon is the presence of a twisted enamel on 
tusks, absent in Notiomastodon platensis. As all the tusk specimens studied did not show such spiral, thus, they were assigned to $N$. platensis. When UFRB-PV376 is compared to other specimen DGM104M (Mothé et al., 2010), both have the same clover shape of the cusps. UFRB-PV4176 has very similar cusps to those of MAP 927, described by Marcon (2008). The cusp was cone-shaped and the number of conulids was similar. The specimen UFRB-PV736 was similar to the description of the specimen MOM 0005 by Marcon (2008). Although the main cusps on the fourth and fifth lophid of the two specimens were in fairly similar positions, UFRBPV736 presented two conulids in the fifth lophid, which was in contrast to MOM 0005. UFRB-PV377 was also observed to have a similar shape as MOM 0005, on account of a similar number of cusps in both. In addition, the main cusps of the fifth lophid were united into a single lophid similar to that in MOM 0005; however, the groove is deeper than in UFRB-PV377. When the measurements (Table 3) and the morphology of UFRB-PV669 were compared with those of MN4208-V, it was observed that UFRB-PV669 had a larger size than MN4208-V, because it was the last cervical vertebra and the vertebrae in the thoracic region tend to be larger. When UFRB-PV1096 were compared with MN4208-V, it was observed that they had similar size, probably because they were on near positions in the thoracic region. While the vertebral center of MN4208-V is convex in cranial view, the curvature in UFRB-PV669 was almost imperceptible and in UFRB-PV1096 it was straight. Nevertheless, they were all similar due the common characteristics of being broad and short vertebrae with rounded vertebral centers. Thus, the specimens were assigned to the species $N$. platensis.

Table 3. Comparative measurements (in mm) of vertebra UFRB-PV660, 669, 1096, 4034 with the specimens MN2529-V, 4208-V, 4354-V. Abbreviations: L, length; W, width; $\mathrm{H}$, height.

\begin{tabular}{llll}
\hline Specimen & L & W & H \\
\hline UFRB-PV 660 & 66.1 & 148.9 & 154.9 \\
UFRB-PV 669 & 59.9 & 155.4 & 130.2 \\
UFRB-PV 1096 & 34.4 & 115.3 & 83.6 \\
UFRB-PV 4034 & 65.5 & 140.8 & 157.3 \\
MN 2529-V & 114.2 & 122.4 & 120.8 \\
MN 4208-V & 49.6 & 115.7 & 92.9 \\
MN 4354-V & 80.9 & 116.8 & 145.9 \\
\hline
\end{tabular}

The specimens UFRB-PV660 and UFRB-PV4034 were compared with MN4354-V and MN2529-V, and the measurements (Table 3) varied due to fragmentation. Nevertheless, the morphology of the specimens was similar to specimens used for comparison. The thoracic vertebrae are wider than vertically elongated and had a nearly triangular shape. The specimens studied showed similarity to those used for comparison; their centers had a slightly convex shape in the cranial view, while they appeared concave in the caudal view. This allowed a better weight support between the thoracic vertebrae when aligned in the column. The specimens were identified as belonging to $N$. platensis. From the measurements presented in Table 2 , the width of the proximal end of the specimen UFRB-PV2116 is larger in comparison to the size of the specimens DGM46-M and DGM80-M. When compared to the material studied by Molena (2012), the measurements of the specimens are within the range described for $N$. platensis. Despite the missing anconeus process and olecranon in the specimen UFRB-PV2116, it was still possible to observe part of the trochlear notch in the proximal region, as well as the lateral and medial coronoid process. Their forms were similar to those of DGM 46-M, 80-M, and 148-M, which had a shallow and oval-shaped surface.

The dimensions of the specimen UFRB-PV534 (Table 4) were compared with those of other specimens and were found to be within the range observed for the family. Particularly, as presented in Table 4, the size of the ectal and sustentacular facets varied considerably across individuals of the same species, which was corroborated by Molena (2012). Another difference was observed between the studied specimen and the specimen DGM147-M (a), which belongs to a juvenile individual. Here, the trochlea of DGM147-M (a) is smaller in size and height and has no grooves, its lateral groove was unmarked, and its navicular facet had a smaller size. When the specimens UFRB-PV534, DGM147-M (b) and MN3896-V were compared, the shape of the navicular facet varied significantly, exhibiting long and wide, as well as short and narrow formats. In the distal view, the ectal facet has nearly circular shaped, being longer in UFRB-PV534 than in DGM147-M (a), and the sulcus tali is clearly visible in DGM147-M (a). When the specimen UFRB-PV1689 was compared with the material described by Smuts \& Bezuidenhout (1994), it seems to have similar shapes. In both, the anterior region was wider than the diaphysis region and

Table 4. Comparative measurements (in mm) of astragalus UFRB-PV534 with the specimens DGM147-M (a), DGM147-M (b), MN3896-V, MCN-PV1061H, MCN-PV2381. Abbreviations: L, length; W, width; H, height; LESL, longer ectal surface length; LLSS, longer length of the sustentacular surface; NW, navicular width; NL, navicular length. * Dimensions taken from Molena (2012).

\begin{tabular}{llllllll}
\hline Specimen & L & W & H & LESL & LLSS & NW & NL \\
\hline UFRB-PV 534 & 135.2 & 146.6 & 91.5 & 94.1 & 101.2 & 74.8 & 725.3 \\
DGM 147-M (a) & 99.6 & 136.4 & 73.8 & 88.3 & 87.7 & 43.5 & 79.4 \\
DGM 147-M (b) & 109.4 & 117.7 & 51.6 & - & - & 90.8 & 93.3 \\
MN 3896-V & 127.1 & 156.1 & 68.7 & 108.7 & 90.8 & 50.5 & 110.8 \\
MCN-PV & $154^{*}$ & $150.5^{*}$ & $30.7^{*}$ & $88.7^{*}$ & $98.4^{*}$ & $80.4^{*}$ & $127.4^{*}$ \\
1061H & $105.1^{*}$ & $94.6^{*}$ & $64.1^{*}$ & $71.8^{*}$ & $67.1^{*}$ & $42.2^{*}$ \\
MCN-PV 2381 & & & & & $73.8^{*}$ \\
\hline
\end{tabular}


the distal region had two continuous articulating facets having a convex shape. As the post-cranial elements of $C$. hyodon and $N$. platensis are very similar, the single UFRB-PV1689 specimen has not sufficient diagnostic features to identify at species level. However, the specimen was collected in association with other materials which, according to Mothé et al. (2012), could be considered diagnostic. Thus, this specimen was assigned to $N$. platensis.

\section{DISCUSSION}

\section{Age of individuals}

The process of dental replacement of Proboscidea suggests that it occurs in a substitutive manner, wherein the $\mathrm{dp} 2 / 2$ teeth are formed in the first month and lost when the animal is one year old; the dp $3 / 3$ teeth develop until the sixth month being lost around seven years old; while dp4/4 are observed in the first year and fall off at the age of 11 years (Mothé et al., 2010). The permanent molar teeth $\mathrm{m} 1 / 1, \mathrm{~m} 2 / 2$, and $\mathrm{m} 3 / 3$ appear around 10,14 , and 28 years old, respectively, while they are lost when individuals are around 22 years, 40 years, and $\mathrm{m} 3 / 3$ are use until the wear stage 4 or complete wear. In addition, the degree of dental wear presented in Table 1 is also important for the inference of age groups.

Based on this, it was possible to identify the age of seven individuals (Table 5) and, following Mothé et al. (2010), recognize them in five age groups. One individual is an immature (0-12 years), one sub-adult (13-24 years), two adults (25-36 years), two mature adults (37-48 years), and one senile adult (49-60 years). When the postcranial bones were analyzed, it was possible to infer that the specimen UFRB-PV2116 probably is a senile adult, due to their rough texture, which is a common characteristic in mammals of advanced age. The specimen UFRB-PV523 possibly is a subadult individual because their epiphyses are partially fused.

Most of the individuals studied here are mature adults (44.4\%). Among the studied fossiliferous localities, the material from municipality of Santaluz could represent a complete population, composed of immature, mature adult, and senile individuals. However, since the specimens were collected from three different tanks which were not dated, it would be premature to assume that they belonged to the same population. In addition, it was not possible to make inferences about the patterns of preservation and selectivity of age in each locality, because the sample size in other municipalities was very small.

\section{Proboscidea records from Bahia State}

The Proboscidea records for Bahia state are from 32 different localities (Table 6), suggesting that the fossil record of proboscideans is rich in this state. This fossil record can be classified into two groups: one of diagnostic materials for the species of South America, and other with no diagnostic specimens in specific level. The specimens from only eight localities could be identified at species level, Notiomastodon platensis, an endemic species of South America and the only recorded in Brazil (Mothé \& Avilla, 2015; Mothé et al., 2017). When its occurrence is plotted on the map (Figure 9), the record of $N$. platensis is restricted to the Northeastern region of Bahia, whereas only indeterminate proboscideans are found in other regions of the state. Thus, there is a need to search for more Proboscidea fossils with diagnostic characteristics in order to increase the knowledge of the fossiliferous diversity of these mammals in the Northeastern Region of Brazil.

Most of the fossils from Bahia state were found in natural tank deposits (Figure 9), which were very common in northeastern Brazil. Besides, the fossils of Proboscidea were collected from cave deposits from only three localities. This could be associated with the size of the animals, which could be a factor preventing their entry in caves. The studies on African elephants (e.g. Bowell et al., 1996) have reported that the animals entered caves in search of the salt present on the walls. This behavior is probably shared by the South American proboscideans, which could be a reason for the presence of their fossils in caves. It could also be hypothesized that their bones were carried into the caves by floods (Cartelle, 1992). Therefore, the findings of Proboscidea fossils in caves are probably isolated cases where the living animals were accidentally trapped, or their bones were carried into the caves after their death.

Another observation from most studies, especially those in the $20^{\text {th }}$ century, is that detailed information about the locality of the specimens was not available. In addition, most of the records did not determine the studied bone fossils. The studies published after 1990 presented more information

Table 5. Age of individuals based on dental identification and the level of tooth wear. Abbreviations: R, right; L, left. *Follow Mothé et al. (2010).

\begin{tabular}{|c|c|c|c|c|}
\hline Specimen & Tooth & Locality & Wear stage* & Age (years)* \\
\hline UFRB-PV376 & $\mathrm{M}^{2} \mathrm{r}$ & João Dourado & 3 & 29.6 util 35 \\
\hline UFRB-PV377 & $\mathrm{M}_{3} \mathrm{r}$ & João Dourado & 2 & 41 util 47 \\
\hline UFRB-PV736 & $\mathrm{M}_{3} 1$ & Lagoa Escura, Santaluz & 2 & 41 util 47 \\
\hline UFRB-PV759 & $\mathrm{M}^{3} \mathrm{r}$ & $\begin{array}{l}\text { Lagoa das Abelhas, } \\
\text { Guanambi }\end{array}$ & $0+$ & 28 util 34 \\
\hline UFRB-PV4176 & $\mathrm{M}_{1}$ & Vargem Grande, Santaluz & 1 & 10 util 12.5 \\
\hline MGUFBA1492 & $\mathrm{M}_{2} 1$ & Nordestina & 1 & 19 util 24 \\
\hline MGUFBA1491 & $\mathrm{M}_{3} \mathrm{r}$ & Nordestina & 4 & $53+$ \\
\hline
\end{tabular}




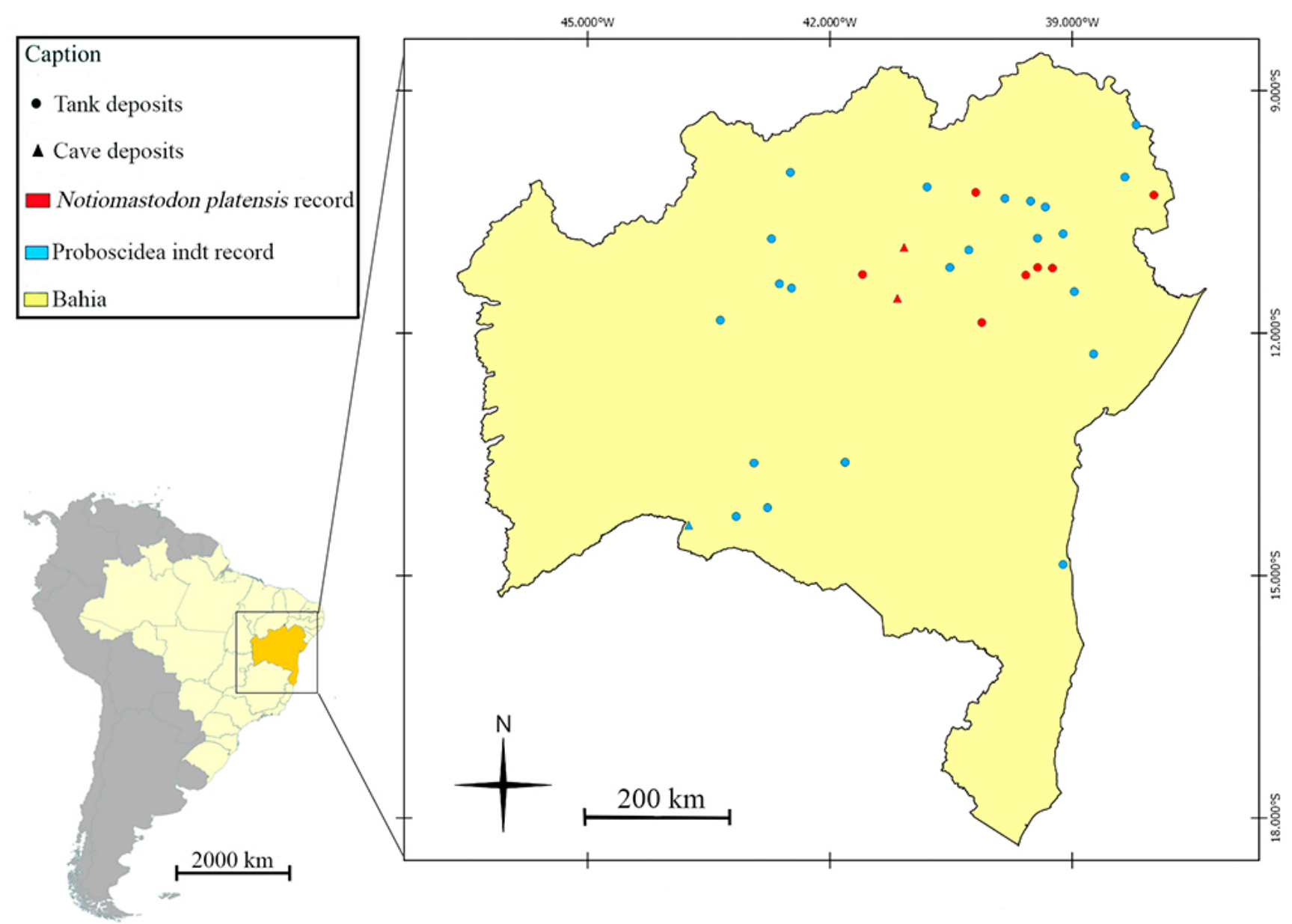

Figure 9. Map with Proboscidea distribution in tanks and caves for the Bahia State.

about the fossils and especially their age, wherein all the fossils were observed to belong to the Late Pleistocene.

The present contribution increases the knowledge on Proboscidea, as it has reported eight new fossiliferous sites across six municipalities from Bahia state, Brazil, which corresponds to $22 \%$ of the findings of Proboscidea in this state. Three of these deposits contained fossils of $N$. platensis. The study also describes the materials found and information about fossil deposits in detail. From this study, it is evident that despite the number of records in Bahia, the studies on their range were not distributed equally. As mentioned earlier, the record of $N$. platensis is restricted to the northeastern region of the state, while other regions have been poorly explored. The regions with little or no record are restricted to the extreme north, west, and south of the state, where additional studies are required to explore potentially novel findings.

\section{CONCLUSIONS}

From the findings of this study, it can be concluded that six municipalities had individuals belonging to Proboscidea, in which $N$. platensis was recorded in the localities of Lagoa Escura, Vargem Grande, Várzea Funda, and the municipality of João Dourado. On the other hand, the municipalities of Caldeirão Grande, Nordestina, Teofilândia, and Guanambi recorded the occurrence of indeterminate Proboscidea. The age of the individuals could be determined from some of the identified specimens, and were classified into five age groups (immature, sub-adult, adult, mature-adult, and senileadult). Bahia has an extensive record of Proboscidea, with a total of 32 locations having their occurrence. Among these records, only eight locations demonstrated the existence of the species $N$. platensis. It is clear that the regions with little or no record of these individuals require additional studies to find new fossils. 
Table 6. Survey on the Proboscidea fossils found in the Bahia State as well as information about the identification, specimen, collection site, and age.

\begin{tabular}{|c|c|c|c|c|}
\hline Taxon & Specimen & Collection site & Age & Reference \\
\hline Notiomastodon platensis & Tusk & Toca dos Ossos, Ourolândia & Late Pleistocene & $\begin{array}{l}\text { Cartelle (1992) } \\
\text { Revised Mothé et al. (2017) }\end{array}$ \\
\hline N. platensis & Molar and tusk & $\begin{array}{l}\text { Gruta dos Brejóes, Morro } \\
\text { do Chapéu }\end{array}$ & No dating & $\begin{array}{l}\text { Cartelle (1992) } \\
\text { Revised Mothé et al. (2017) }\end{array}$ \\
\hline N. platensis & Tusk & Jaguarari & No datting & Mothé et al. (2017) \\
\hline N. platensis & Tusk & $\begin{array}{l}\text { Coronel João Sá, Fazenda } \\
\text { Caraíba }\end{array}$ & No datting & $\begin{array}{l}\text { Dantas \& Zucon (2007) } \\
\text { Revised Mothé et al. (2017) }\end{array}$ \\
\hline N. platensis & Tusk fragment & $\begin{array}{l}\text { Baixa Grande, Lagoa do } \\
\text { Rumo }\end{array}$ & No datting & Ribeiro et al. (2013) \\
\hline N. platensis & Tusk and molar fragment & Lagoa Escura, Santaluz & Late Pleistocene & Present study \\
\hline N. platensis & Tusk and molar fragment & Vargem Grande, Sanaluz & Late Pleistocene & Present study \\
\hline N. platensis & Tusk fragment & Várzea Funda, Santaluz & Late Pleistocene & Present study \\
\hline N. platensis & Tusk & JoãoDourado & Late Pleistocene & Present study \\
\hline Proboscidea Indet. & Indefinite fragment & Rio das Contas & No datting & Casal (1817) \\
\hline Proboscidea & Indefinite fragment & PedraVermelha & No datting & Holland (1920) \\
\hline Proboscidea Indet. & Indefinite fragment & Gentío do Ouro & No datting & Morais Rego (1926) \\
\hline Proboscidea Indet. & Indefinite fragment & Pilão Arcado & No datting & Morais Rego (1926) \\
\hline Proboscidea Indet. & Indefinite fragment & $\begin{array}{l}\text { Paulo Afonso, Pedra do } \\
\text { Navio }\end{array}$ & No datting & Hartt (1941) \\
\hline Proboscidea Indet. & Indefinite fragment & Vitória da Conquista & No datting & Paula-Couto (1953) \\
\hline Proboscidea Indet. & Molar & Palmas do Monte Alto & No datting & $\begin{array}{l}\text { Simpson \& Paula-Couto } \\
\text { (1957) } \\
\text { Revised Mothé et al. (2017) }\end{array}$ \\
\hline Proboscidea Indet. & Indefinite fragment & Jeremoabo & No datting & $\begin{array}{l}\text { Simpson \& Paula-Couto } \\
\text { (1957) }\end{array}$ \\
\hline Proboscidea Indet. & Indefinite fragment & Riacho de Santana & No datting & Cartelle (1992) \\
\hline Proboscidea Indet. & Indefinite fragment & Campo Formoso & No datting & Campos \& Campos (1976) \\
\hline Proboscidea Indet. & Indefinite fragment & Monte Santo & No datting & Cartelle (1992) \\
\hline Proboscidea Indet. & Molar germs & Toca dos Ossos, Ourolândia & Late Pleistocene & $\begin{array}{l}\text { Cartelle (1992) } \\
\text { Revised Mothé et al. (2017) }\end{array}$ \\
\hline Proboscidea Indet. & Molar & Toca dos Ossos, Ourolândia & Late Pleistocene & $\begin{array}{l}\text { Cartelle (1992) } \\
\text { Revised Mothé et al. (2017) }\end{array}$ \\
\hline Proboscidea Indet. & Mandibular branch fragment & Toca dos Ossos, Ourolândia & Late Pleistocene & $\begin{array}{l}\text { Cartelle (1992) } \\
\text { Revised Mothé et al. (2017) }\end{array}$ \\
\hline Proboscidea Indet. & Humerus distal fragment & Jacobina & No dating & $\begin{array}{l}\text { Cartelle (1992) } \\
\text { Revised Mothé et al. (2017) }\end{array}$ \\
\hline Proboscidea Indet. & Molar fragment & Sítio novo, Matina & No datting & Riff et al. (2008) \\
\hline Proboscidea Indet. & Indefinite fragment & Quijingue & No datting & Machado et al. (2011) \\
\hline Proboscidea Indet. & Molar fragment & Toca Fria, Iuiú & Late Pleistocene & Mothé et al. (2017) \\
\hline Proboscidea Indet. & Indefinite fragment & Formação de Vazantes & No datting & Mothé et al. (2017) \\
\hline Proboscidea Indet. & Indefinite fragment & Xique Xique & No datting & Mothé et al. (2017) \\
\hline Proboscidea Indet. & Indefinite fragment & Serra do Assuruá & No datting & Mothé et al. (2017) \\
\hline Proboscidea Indet. & Indefinite fragment & $\begin{array}{l}\text { Fazenda de Bom Jesus de } \\
\text { Meira, Rio das Contas }\end{array}$ & No datting & Mothé et al. (2017) \\
\hline Proboscidea Indet. & Indefinite fragment & Serra da Itiuba & No datting & Mothé et al. (2017) \\
\hline Proboscidea Indet. & Indefinite fragment & Serra da Itiuba/Monte Santo & No datting & Mothé et al. (2017) \\
\hline Proboscidea Indet. & Tusk fragment & Teofilândia & Late Pleistocene & Present study \\
\hline Proboscidea Indet. & Mandible & Nordestina & Late Pleistocene & Present study \\
\hline Proboscidea Indet. & Incomplete ulna & Caldeirão Grande & Late Pleistocene & Present study \\
\hline Proboscidea Indet. & Molar fragment & $\begin{array}{l}\text { Lagoa das Abelhas, } \\
\text { Guanambi }\end{array}$ & Late Pleistocene & Present study \\
\hline
\end{tabular}




\section{ACKNOWLEDGMENTS}

We thank VALEC Engenharia, Construções e Ferrovias, S.A. and CNPq (Edital MCT/CNPq 14/2010 Universal, 475291/2010-7) for the financial resources for fieldwork and analysis. We thank Simone Morais and the Museu de Geociências from Universidade Federal da Bahia for provide the studied materials. We also thank Museu Nacional as well the Museu de Ciências da Terra from Departamento Nacional de Produção Mineral for access to the comparison specimens. We thank the population of the municipalities of Santaluz, Caldeirão Grande, Guanambi and João Dourado for the support in the fieldworks. Also, to D. Mothe for all the contribution to the improvement of this manuscript. Finally, we thank the anonymous reviewers whose corrections and suggestions improved the quality of this manuscript.

\section{REFERENCES}

Ameghino, F., 1888. Rápidas diagnosis de algunos mamíferos fósiles nuevos de la República Argentina. Buenos Aires, Obras Completas, $17 \mathrm{p}$.

Araújo-Júnior, H.I.; Porpino, K.O.; Ximenes, C.L. \& Bergqvist, L.P. 2013. Unveiling the taphonomy of elusive natural tank deposits: a study case in the Pleistocene of northeastern Brazil. Palaeogeography, Palaeoclimatology, Palaeoecology, 378:5274. doi:10.1016/j.palaeo.2013.04.001

Bowell, R.J.; Warren, A. \& Redmond, I. 1996. Formation of cave salts and utilization by elephants in the Mount Elgon region, Kenya. London, The Geological Society, p. 63-79 (Special Publications 113). doi:10.1144/GSL.SP.1996.113.01.06

Cabrera, A., 1929. Una revisión de los mastodontes argentinos. Revista del Museo de La Plata, 32:61-144.

Cartelle, C. 1992. Edentata e megamamiferos herbívoros extintos da Toca dos Ossos (Ourolândia, BA, Brasil). Programa de PósGraduação em Morfologia, Universidade Federal de Minas Gerais, Ph.D. thesis, 301 p.

CPRM, SERVIÇO GEOLÓGICO DO BRASIL. Available at: http://www.cprm.gov.br/publique/cgi/cgilua. exe/sys/start.htm; accessed on August 2015.

Dantas, M.A.T. \& Tasso, M.A.L. 2007. Megafauna do Pleistoceno final de Vitória da Conquista, Bahia: taxonomia e aspectos tafonômicos. Scientia Plena, 3:30-36.

Dantas, M.A.T.; Xavier, M.C.T.; França, L.M.; Cozzuol, M.A.; Ribeiro, A.S.; Kinoshita, A. \& Baffa, O. 2013. A review of the time scale and potential geographic distribution of Notiomastodon platensis (Ameghino, 1888) in the late Pleistocene of South America. Quaternary International, 317:73-79. doi:10.1016/j. quaint.2013.06.031

Dantas, M.A.T. \& Zucon, M.H. 2007. Sobre a ocorrência de fosseis da megafauna do Pleistoceno final em Coronel João de Sá, Bahia, Brasil. Revista Universidade de Guarulhos, 6:191-200.

Farias, F.H.C.; Ribeiro, R.C. \& Carvalho, I.S., 2013. Feições de modificações em fósseis da megafauna do Quaternário tardio da Lagoa do Rumo, Baixa Grande, Bahia, Brasil. In: CONGRESSO BRASILEIRO DE PALEONTOLOGIA, 23, 2013. Boletim de Resumos, Gramado, SBP, p. 224-225.

Ferretti, M.P. 2010. Anatomy of Haplomastodon chimborazi (Mammalia, Proboscidea) from the late Pleistocene of Ecuador and its bearing on the phylogeny and systematics of
South American gomphoteres. Geodiversitas, 32:663-721. doi:10.5252/g2010n4a3

Holland, W.J. 1920. Fossil mammals collected at Pedra Vermelha, Bahia, Brazil, by Gerald A. Waring. Annals of the Carnegie Museum, 13:224-232.

Illiger, C. 1811. Prodromus systematis mammalium et avium additis terminis zoographicis utriusque classis, eorumque versione germanica. Illiger, Johann Karl Wilhelm, 301 p..

Laws, R.M. 1966. Age criteria for African elephant, Loxodonta a. aficana. East African Wildlife Journal, 4:1-37.

Lôbo, L.S.; Scherer, C.S. \& Gomes, A.C.F. 2013. Novo depósito fossilifero em João Dourado, Região Centro-Norte da Bahia, Brasil. Porto Alegre, Sociedade Brasileira de Paleontologia, p. 114 (Paleontologia em Destaque 66).

Machado, C.B.; Scherer, C.S. \& Oliveira, T.V. 2011. Afloramento "Sítio": uma nova localidade fossilífera para o Pleistoceno da Bahia.In:CONGRESSOBRASILEIRODEPALEONTOLOGIA, 22, 2011. Boletim de Resumos, Natal, SBP, p. 621-624.

Marcon, G.T.G. 2008. Contribuição para o estudo dos Proboscidea (Mammalia, Gomphotheriidae) do Quaternário do estado do Rio Grande do Sul, Brasil. Revista Universidade Guarulhos, 7:93-109.

Molena, F.P. 2012. Variação individual no esqueleto apendicular de mastodontes (Proboscidea: Gomphotheriidae) proveniente de São Bento do Uma, Pernambuco, Brasil. Instituto de Biociências, Universidade de São Paulo, M.Sc. dissertation, 185 p. doi:10.11606/D.41.2012.tde-01052013-093838

Mothé, D. \& Avilla, L. 2015. Mythibusting evolutionary issues on South American Gomphotheriidae (Mammalia: Proboscidea). Quaternary Science Reviews, 110:23-35. doi:10.1016/j. quascirev.2014.12.013

Mothé, D. et al. 2017. Sixty years after 'The mastodonts of Brazil': the state of the art of South American proboscideans (Proboscidea, Gomphotheriidae). Quaternary International, 443:52-64. doi:10.1016/j.quaint.2016.08.028

Mothé, D.; Avilla, L.S.; Cozzuol, M.A. \& Winck, G.R. 2012. Taxonomic revision of the Quaternary gomphotheres (Mammalia: Proboscidea: Gomphotheriidae) from the South American lowlands. Quaternary International, 276-277:2-7. doi:10.1016/j.quaint.2011.05.018

Mothé, D.; Avilla, L.S. \& Winck, G.R. 2010. Population structure of the gomphothere Stegomastodon waringi (Mammalia: Proboscidea: Gomphotheriidae) from the Pleistocene of Brazil. Anais da Academia Brasileira de Ciências, 82:983-996. doi:10.1590/S0001-37652010005000001

Paula-Couto, C. 1953. Paleontologia brasileira: mamíferos. Rio de Janeiro, Instituto Nacional do Livro, 520 p.

Ribeiro, R.C. \& Carvalho, I.S. 2009. Megafauna do Quaternário tardio de Baixa Grande, Bahia, Brasil. Anuário do Instituto de Geociências, 32:42-50.

Riff, D.; Avilla, L.S.; Mothé, D. \& Abranches, C.T.S. 2008. Novos registros de megamamiferos para o sertão do sudeste baiano. In: SIMPÓSIO BRASILEIRO DE PALEONTOLOGIA DE VERTEBRADOS, 6, 2008. Boletim de Resumos, Ribeirão Preto, SBP, p. 177-178.

Santos, D.R. \& Scherer, C.S. 2013. Nova localidade fossilífera para o Pleistoceno da Bahia, Brasil. In: CONGRESSO BRASILEIRO DE PALEONTOLOGIA, 23, 2013. Boletim de Resumos, Gramado, SBP, p. 277.

Scherer, C.S.; Lôbo, L.S.; Gomes, A.C.F. \& Santos, D.R. 2013. Novo depósito fossilífero pleistocênico em Lagoa Escura, Santa Luz, Bahia. Porto Alegre, Sociedade Brasileira de Paleontologia, p. 119 (Paleontologia em Destaque 66). 
Scherer, C.S..; Pales, L.F.M.; Rosa, M. \& Silva, S.A. 2017. Chronological, taphonomical, and paleoenvironmental aspects of a Late Pleistocene mammalian fauna from Guanambi, Bahia, Brazil. Journal of South American Earth Sciences, 79:95-110. doi:10.1016/j.jsames. 2017.07.016

Silva, J.A.; Leal, L.A.; Cherkinsky, A. \& Dantas, M.A.T. 2019. Late Pleistocene meso-megamammals from Anagé, Bahia, Brazil: taxonomy and isotopic paleoecology $\left(\delta^{13} \mathrm{C}\right)$. Journal of South American Earth Sciences, 96:102362. doi:10.1016/j. jsames.2019.102362

Silva, M.R.T.; Silva, S.A.; Pales, L.F.M. \& Scherer, C.S. 2014. Novas evidencias fósseis de Eremotherium laurillardi (Xenarthra, Megatheriidae) o município de Santa Luz, Bahia, Brasil. In: SIMPÓSIO BRASILEIRO DE PALEONTOLOGIA DE VERTEBRADOS, 9, 2014. Boletim de Resumos, Vitória, SBP, p. 130 .
Simpson, G.G. \& Paula-Couto, C. 1957. The Mastodonts of Brazil. Bulletin of American Museum of Natural History, 112:125-190.

Smuts, M.M.S. \& Bezuidenhout, A.J. 1994. Osteology of the pelvic limb of the African elephantt (Loxodonta africana). Journal of Veterinary Research, 61:51-66.

Tassy, P. 1996. Dental homologies and nomenclature in the Proboscidea. In: J. Shoshani \& P. Tassy (eds.) The Proboscidea, evolution and palaeoecology of elephants and their relatives, Oxford University Press, p. 21-25.

Ubilla, M. 2009. Megafauna Pleistocênica: evolução e extinção na América do Sul. In: Á.A.S. Da-Rosa (ed.) Vertebrados fósseis de Santa Maria e região, Pallotti, p. 303-320.

Received in 09 October, 2019; accepted in 30 April, 2020. 